\title{
フェライト粉体による䣲母菌の殺菌効果
}

\author{
正員吉 村昇 (秋田大) \\ 准員鈴木 久 雄（秋田大）
}

\section{Sterilizing Effect on Yeast Cells by Ferrite Powders}

Noboru Yoshimura, Member, Hisao Suzuki, Associate Member (Akita University)

\section{キーワード：磁気，フェライト，殺菌, 醉母菌}

現在, 直流磁界による醉母菌の殺菌効果について検 討を進めている。アモルファスフィルムを用い, 磁束 密度 $6,000 \mathrm{G}$ の磁界を 12 時間䤃母菌に照射した場合 に, 生菌率が $0.25 \%$ に低下することは先に報告し だ(1)。しかし，アモルファスフィルムでは殺菌効果を 上げるために，高い磁束密度と長い照射時間を必要と すること，更に生菌率を $0 \%$ にすることが難しいこと が明らかになり，そこでアモルファスフィルムに代わ りフフェライト粉体を用いて検討した。

本研究で使用した醉母菌は前報(1) と同様, 清酒用 の協会七号(学名: Saccharomyces cerevisiae)であ る。酵母細胞の大きさは $5 \mu \mathrm{m}$ である。醉母菌には四 つの生育過程があるが，本研究では停止期の醭母菌を 用いた。

酵母菌の培養には, YPD (Yeast extracts, Polypeptone, Dextrose, 蒸留水を1:2:2:100の割合 で混合した溶液）培地を用いた。恒温槽（田葉井製， $\mathrm{LC}-222)$ を用いて $155^{\circ} \mathrm{C}, 2$ 時間の乾熱殺菌済みの $L$ チューブ(長さ: $170 \mathrm{~mm}$, 内径: $16 \mathrm{~mm} \phi) に Y P D$ 培地 $5 \mathrm{~m} l$ と 1 白金耳の醉母菌を入れ，これを振盪培

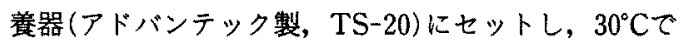
17〜20 時間振笽すると, 菌数は $(2 \sim 3) \times 10^{8} \mathrm{cells} / \mathrm{m} l$ となる。希釈はファルコンチューブを用いて行い，10 倍希积を 5 回繰返し, 菌数を $(2 \sim 3) \times 10^{3} \mathrm{cells} / \mathrm{m} l$ と したものを供試菌とした。この供試料を試験管に 15 $\mathrm{m} l$ とり磁気照射試験用とした。同一条件ではこれを 5 回繰返した。

直流電磁石 (三井造船製)を用いてギャップ間の磁束 密度を $2,000 \mathrm{G}$ あるいは $1,000 \mathrm{G}$ に設定した。2,000 G を超えると, 試験管が強く磁極に引つ張られ, 滑らか な振盪が不可能となるため,ここでは $2,000 \mathrm{G}$ と $1,000 \mathrm{G}$ にし, 試験管は磁極間で上下に周期 $2 \mathrm{~s} /$ サイ
クルで 1 時間, 30 分，および 15 分間振温した。 試験管内にはスチレンアクリル樹脂 (厚さ $2 \sim 3 \mu \mathrm{m}$ ) でコーティングしたフェライト粉体(直径: $80 \mu \mathrm{m}$, $\mathrm{TDK}$ 製)を $6 \mathrm{~g}$ 入れた。なお,フェライト粉体の殺菌 は, アルコール浸漬後紫外線照射を 24 時間行った。

磁気照射後は YPD 寒天培地により $28^{\circ} \mathrm{C} て 2$ 日間培 湌し、コロニーを計数した。本研究では次式で示され る生菌率を比較に用いた。

$$
\text { 生菌率 }(\%)=\frac{\text { 磁気照射区のコロニ一数 }}{\text { 駢始前のコロニー数 }} \times 100
$$

実験結果を表 1 に示す。いずれの場合も顕著な殺菌効 果が認められる。2,000 G と $1,000 \mathrm{G}$ を比較した場合, 同一照射時間における生菌率は，2,000 G のほうが $1,000 \mathrm{G} よ り も$ 低い。なお, $2,000 \mathrm{G}$ の磁極間に試験管 を振盪させないで静置した場合には, 照射 1 時間で生 菌率は 3 回の同一条件における実験の平均值で $101.2 \%, 30$ 分で $94.1 \%$ となり, 殺菌効果はほとんど 認められない。

図 1 に試験後メチレンブルーで着色した醉母菌の顕 微鏡写真を示す。写真 (a) は明るく光っており生存し ている菌，（b)は形は残っているが死喴した菌，(c)

表 1 生菌率の磁気照射時間依存性 Table 1. Time dependence of survivability for Yeast cells against magnetic radiation time $t$.

\begin{tabular}{|c|c|c|c|c|}
\hline \multirow{2}{*}{\multicolumn{2}{|c|}{ 印加酳東密度 $(\mathrm{G})$}} & \multicolumn{3}{|c|}{ 生菌年(\%) } \\
\hline & & $t=60 \mathrm{~min}$ & $t=30 \mathrm{~min}$ & $t=15 \mathrm{~min}$ \\
\hline \multirow{3}{*}{2,000} & 霞大值 & 0.40 & 0.80 & 1.41 \\
\hline & 最小值 & 0 & 0.30 & 1.08 \\
\hline & 平均值 & 0.20 & 0.58 & 1.19 \\
\hline \multirow{3}{*}{1,000} & 最大值 & 0.50 & 5.78 & - \\
\hline & 最小値 & 0.22 & 2.53 & - \\
\hline & 平均値 & 0.32 & 4.12 & - \\
\hline
\end{tabular}




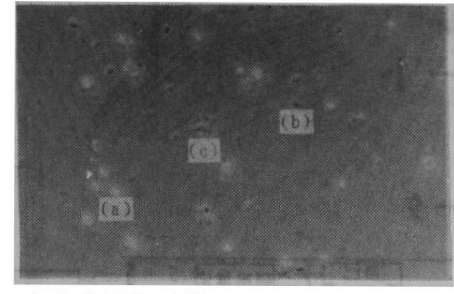

(a) 生きている菌

(b) 形の残つたまま死んている菌

（c）細胞賓の破懐された菌

図 1 磁気照射後の醉母菌の顕微鏡写真

Fig. 1. Microscopic photograph of

Yeast cells after test.

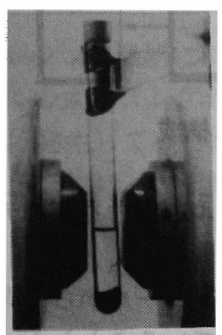

(a)凝集時 $(B=0 \mathrm{G})$

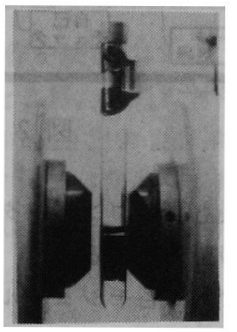

(b) 分散時 $(B=2,000 \mathrm{G})$
図 2 フェライト粉体の分散と凝集 Fig. 2. Scattering and condensation of ferrite powders.

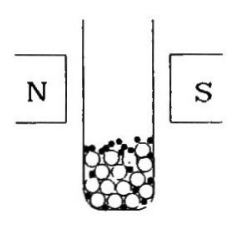

(a) 凝集時

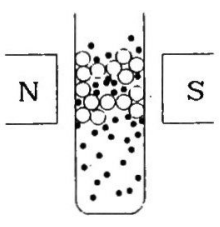

(b) 分散時
○:フェライト粉体・: 醇母菌

図 3 酵母菌とフェライト粉体の移動モデル図

Fig. 3. Model figure for motion between Yeast cells and ferrite powders.

は細胞壁の破壊された菌である。

表 1 より試験管を振盪した場合にのみ酵母菌の死滅 することが明らかとなった。この結果より, 酵母菌死 滅の原因としては，磁界中で試験管を上下に振盪する ことにより，フェライト粉体の分散(磁界内) $\rightarrow$ 凝集 (磁界外) $\rightarrow$ 分散 (磁界内) $\rightarrow \cdots$ (図 2 参照) が繰返される
ためと推測される。すなわち，図３に示すように分散 時にフェライト粉体間に取込まれた醭母菌が, 凝集時 に局部的な水の圧力上昇により細胞壁が一部破壊され るか, あるいは細胞内の増殖因子が破壊される（磁気 機械的効果と称す）ためと推測される。この点につい ては今後十分に検討する予定である。

本研究に対し御援助いただいている秋田県酒造組 合, 秋田県䤑造試験場, 三井造船(株), TDK(株) ᄀ エライト事業部の関係各位, 本学大学院生 伊藤達弥 君に謝意を表す。

(平成 3 年 1 月 8 日受付)

文献

（1）吉村・土井・鈴木・中田・石川：「磁気による醉母菌の死活 制御了, 電学論 $A, 109,45$ (平元-1)

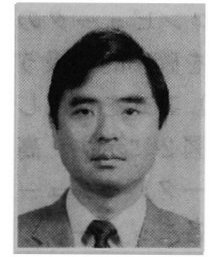

\section{吉 村 昇（正員）}

昭和 18 年 11 月 5 日生。 44 年 3 月秋田大学大学院修士課程電気工学 専攻修了。同年 4 月同大学鉱山学部 電気工学科助手, 講師, 助教授を経 て, 58 年 4 月同教授となり, 現在に至る。工学博士。 電気・電子材料, 特に絶縁材料の劣化現象と絶縁破壊, 誘電体および半導体セラミックスの電気特性および電 磁気工学の生物工学への応用に関する研究に従事。53 年 1 月〜 54 年 8 月クラークソン工科大学客員研究員, 平成元年同大学客員教授。59 年電気学会論文賞受賞。 平成 2 年日本素材物性学会会長。電子情報通信学会, 応用物理学会, 静電気学会, IEEE 会員。

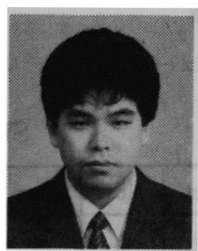

\section{鈴木 久 雄 (准員)}

昭和 41 年 12 月 29 日生。平成元 年 3 月秋田大学鉱山学部電気工学科 卒業。同年 4 月同大学大学院修士課 程電気工学専攻入学, 現在に至る。 電磁気工学の生物工学への応用に関する研究に従事。 